USBAD Uluslararası Sosyal Bilimler Akademi Dergisi -

International Journal of Social Sciences Academy, Yıl 3,

Year 3, Sayı 5, Issue 5, Nisan 2021, April 2021.

e Issn: 2687-2641

\title{
ÖĞRETMEN ADAYLARININ GÜVENLİ GIDA FARKINDALIK DÜZEYLERİNİN BELİRLENMESİ
}

DETERMINATION OF THE TEACHER CANDIDATES' AWARENESS OF FOOD SAFETY

\section{Nida BAYINDIR}

Doç. Dr. Osmangazi Üniversitesi, Eğitim Fakültesi, Temel Eğitim,

Eskişehir/Türkiye.

Assoc. Dr., Osmangazi University, Primary Education, Faculty of Education, Eskisehir/Turkey. nida.bayindir@ogu.edu.tr

ORCID ID: $000000018329358 \mathrm{X}$
Nejla GÜLTEPE

Dr. Osmangazi Üniversitesi, Eğitim

Fakültesi, Temel Eğitim Bilimleri ve Matematik, Eskişehir/Türkiye.

Phd., Osmangazi University, Faculty of Education, Elementary Science and Mathematics Education, Eskisehir/Turkey. nejlagultepe@gmail.com

ORCID ID: 0000-0001-6730-5640X

Makale bilgisi | Article Information

DOI: $10.47994 /$ usbad.850564

Makale Türü / Article Type: Araştırma Makalesi / Research Article

Geliş Tarihi / Date Received: 01.01.2021

Kabul Tarihi / Date Accepted: 05.02.2021

Yayın Tarihi / Date Published: 20.04.2021

Yayın Sezonu / Pub Date Season: Nisan / April

Bu Makaleye Atıf İçin / To Cite This Article: Bayındır, N. \& Gültepe, N. (2021). Öğretmen Adaylarının Güvenli Gıda Farkındalık Düzeylerinin Belirlenmesi. USBAD Uluslararası Sosyal Bilimler Akademi Dergisi 3(5), 160-180.

Intihal: Bu makale intihal.net yazılımınca taranmıştır. İntihal tespit edilmemiştir. Plagiarism: This article has been scanned by intihal. net. No plagiarism detected.

\section{intihal.net}

\section{İletişim: Web: https://dergipark.org.tr/tr/pub/usbad}


Öz: Gıda güvenirliği gıdalarda oluşabilecek fiziksel, kimyasal, biyolojik ve tüm oluşabilecek zararları önlemeye dönük sistematik bir kavramdır. Fiziksel kirlenme, yiyeceklere besin olmayan maddelerin karışmasıdır. Biyolojik kirlenme, toprak ve sudan kaynaklı besinlerde zararlı enzimler, parazit, mantar, bakteri, virüs, küf veya mikroorganizmalara neden olurken, kimyasal kirlenme ise metaller, tarım ilaçları, deterjanlar, plastikler, gıda katkı maddeleri gibi dışarıdan eklenen kimyasal maddelerin neden olduğu kirlenmedir. Öğrencilerin her türlü sorumluluğunu üstelenen öğretmenlerin okul saatleri içerisinde öğrencilerin beslenmelerinden de sorumlu olduğu gerçeği ile gıda güvenliği hakkındaki farkındalıkları önem taşımaktadır. Araştırma, öğretmen adaylarının gıda güvenliği kapsamında gıda hijyen uygulamaları hakkındaki bilgi düzeylerini belirlemeyi amaçlamıştır. Araştırma 2019-2020 akademik yılı güz dönemi ESOGU eğitim fakültesinde sınıf eğitiminde öğrenim gören 14 öğretmen adayı ile gerçekleştirilmiştir. Araştırmada nitel araştırma tekniklerinden fenomenolojik desen kullanılmıştır. Araştırma sonuçlarına göre; adayların gıda güvenirliğine ilişkin herhangi bir ders almadıkları, gıda güvenirliği ile ilgili bilgileri; kişisel çabaları ile sosyal medya ve aileleri ile deneyimlerinden edindikleri ortaya çıkmıştır. Araştırma sonuçlarına göre, adayların güvenli gıdaya yönelik farkındalıklarını arttıran bilimsel araştırmaların yapılması önerilmektedir.

Anahtar sözcükler: Gıda Güvenliği, Besin Kirliliği, Öğretmen Adayı

Abstract: Food safety is a systematic concept aimed at preventing physical, chemical, biological and all possible damages in foods. Physical contamination is the mixing of non-nutrients with food. Biological pollution causes harmful enzymes, parasites, fungi, bacteria, viruses, mold or microorganisms in foods originating from soil and water, while chemical contamination is caused by externally added chemicals such as metals, pesticides, detergents, plastics, food additives. The fact that teachers, who take all kinds of responsibilities for students, are also responsible for the nutrition of students during school time, and their awareness of food safety is important. The study aimed to determine knowledge and awareness of teacher candidates about food hygiene practices within the scope of food safety. The research was conducted on 14 teacher candidates studying at ESOGU education faculty in the fall semester of the 2020-2021 academic year. Phenomenological pattern, one of the qualitative research techniques, was used in the study. According to the research results; It was revealed that the candidates did not take any courses on food safety and that they acquired the information about food safety from their personal efforts and experiences in social media and their family. It was recommended that education on food safety should be given at all levels starting from elementary school level in conclusion.

Keywords: Food Safety, Food Pollution, Primary School 


\section{GİRIŞ}

Dünya nüfusu her geçen gün daha da artmakta, gıda maddelerine olan ihtiyaç da büyümektedir. Ancak artan nüfusun beslenme ihtiyacını karşılayabilmek için tarımsal üretim artık yeterli olmamakta, yapay yollarla ürün olgunlaşmasını kısaltma, ürün depolama süresini arttırma ve genetiği değiştirilmiş tohum üretimleri ile doğallıktan uzaklaşma yollarına gidilmektedir (Hasançebi, 2010: 1).

Avrupa, kontrol ve önleme politikaları, tüketicilerin sağığının yüksek düzeyde korunmasını garanti etmeye odaklanmıştır. Obezite, diyabet, gıda alerjisi ve gıda kaynaklı salgınlar gibi gıda kaynaklı hastalıkların artmasıyla birlikte (Traversa vd., 2017) son yıllarda sağlık bilincinin ve gıda güvenliğinin toplumda daha fazla dikkat çekmesi ile sağııklı gıdaya talep artmıştır.

Güvenli gıda, genel anlamda gıdanın tarladan sofraya kadar kimyasal, fiziksel, duyusal ve biyolojik niteliklerini koruyarak sağlıklı ve güvenilir bir şekilde tüketiciye sunulması ve bunun için alınan önlemleri kapsamaktadır (Onurlubaş ve Gürler, 2016: 33; Erkmen, 2010: 222). Gıda güvenliği ise gıdalarda oluşabilecek fiziksel, kimyasal, biyolojik, her türlü riskin önüne geçilmesi için gerekli olan bütün önlemler olarak tanımlanır. Bu riskler bakteriyel etkiler, parazitler, pestisitler, zehirler, plastik gibi katı atıklar, üretim hataları, kötü beslenme alışkanlıkları tüketicinin maruz kaldığı tehlikelerden bazılarıdır (Artık vd., 2013). Başka bir ifadeyle gıda güvenliği; "sağlıklı ve kusursuz gıda üretimini sağlamak amacıyla, gıdaların; üretim, işleme, muhafaza ve dağıtımları sırasında gerekli kurallara uyulması ve önlemlerin alınması" olarak tanımlanmaktadır (Çetin ve Şahin, 2017: 311).

Gıda güvenliği; genellikle gıda sanitasyonu, gıda kalitesi, gıda beslenmesi ve diğer ilgili içerikleri de içeren kapsamlı bir kavramdır. Aynı zamanda insan hastalıklarına neden olabilecek gıda ile ilgili potansiyel tehlikeleri ifade eder (Dong ve Ching, 2015). Bu hastalıklar besinlerin; fiziksel, biyolojik ve kimyasal olarak kirlenmesinden kaynaklanır. Fiziksel kirlenme, yiyeceklere besin olmayan maddelerin karışmasıdır. Biyolojik kirlenme, toprak ve sudan kaynaklı besinlerde zararlı enzimler, parazit, mantar, bakteri, virüs, küf veya mikroorganizmalara neden olmaktadır. Kimyasal kirlenme ise dışarıdan eklenen kimyasal maddelerin (pestisitler, veteriner ilaçları, endüstriyel kirleticiler, ağır metaller, koruyucu maddeler, sentetik boyalar, tatlandırıcılar, lezzet arttırıcılar vb) neden olduğu kirlenmedir. Besinler 
aracılığıyla alınan mikroorganizmalar ve diğer bulaşanlar ağız yoluyla alındığında sindirim kanalına yerleşir ve enfeksiyonlara yol açar. Pestisit zehirlenmeleri her yıl pek çok çocuğu etkilemekte ve kronik nörolojik ve gelişimsel sağlık sorunlarına neden olmaktadır (Gündoğdu vd., 2016: 62). Ayrıca besin yoluyla insan vücuduna giren bu tip patojenler; akut zehirlenme, kanser, doğum kusurları, kısırlık, sinir sitemi bozuklukları gibi pek çok olumsuzluklara da yol açmaktadır (Kaplan, 2009: 31). Bu kalıntılar ve bulaşanlar, aynı zamanda atmosferde birikerek solunum yolu ile insanlara ulaşmakta ve solunum rahatsızlıklarına ve alerjik reaksiyonlara neden olmaktadır (Sarıtaş, 2012: 6; Güler ve Çobanoğlu, 1994: 16; Kocaman ve Şanlıer, 2014: 156).

Bilinçli bir tüketici; bir ürün ya da hizmeti satın alırken gerçek gereksinimlerini göz önünde tutan, planlı ve belgeli alışveriş yapan, sağlıklı, güvenli, ürünü seçebilen, aynı zamanda kaliteyi denetleyen sosyoekonomik unsurdur (İncedal vd., 2018: 55).

Bireylerin bilinçli bir tüketici olmalarında onların ailelerinden ve okuldan aldıkları eğitimin önemi bir kez daha anlaşılmaktadır. Çocuklar yaşamlarının en önemli süreçlerini okulda geçirmektedir. Fizyolojik, psikolojik ve sosyal gelişim ile büyüme ve gelişmenin hızlı olduğu, yaşam boyu sürebilecek davranışların büyük ölçüde oluştuğu ve bireylerin bilgi almaya ve alışkanlık kazanmaya en elverişli oldukları bu dönem, beslenme davranışlarını geliştirmesinde kritik rol oynamaktadır. Okullarda öğrencilerin sağıklı beslenme davranışlarını geliştirecek ortamlar sağlanması, okul kantinlerinde veya yemekhanelerde öğrencilere sağlıklı ve güvenli besinler sunulması ve bu alanların sağlığa uygun düzenlenip, sağlık bilgisi koşullarına dikkat edilmesi önemlidir (Harmanoğulları ve Yapıcı, 2018: 118).

Traversa ve diğerleri (2017), gıda güvenliği, gıda ve beslenmede gizli alerjenlere yönelik 5 eğitim atölyesi tasarlayarak ilköğretim ve yaz okullarına devam eden çocukları bu atölyelere dâhil ederek bir araştırma gerçekleştirmiştir. Araştırmaya atölyeye 6-11 yaş arası toplam 1708 çocuk katılmıştır. Çocuklar dinleme aktivitelerine, laboratuvar deneylerine, oyun oynamaya ve duyusal deneyimlere katılmış ve çocukların bilgi ve davranışları hakkında gözlemler yapılmıştır. Yaptıkları araştırmada çocukların, birçok yiyeceğin normalde canlı bakteri içerdiğini keşfettiklerinde büyük bir merak duyduklarını gözlemlediler. Çalışmada araştırmacılar çocukların birçoğunun (>\%75) meyve ve sebzelerin tüm yıl boyunca mevcut 
olduğunu ve belirli bir dönemle ilgili olmadığını düşündüklerini, çok azının (<\%25), taze balıkları parazitlerden korumak için uygulanacak tedavinin dondurma olduğunu bildiğini ifade etmektedir. Araştırmacılara göre gıda güvenliği ve beslenme eğitim deneyimlerine dâhil olan çocukların, gıda kaynaklı hastalıkları önlemek için doğru davranışlar konusunda farkındalıklarını artırma ve gıda tüketimi hakkında kendi eleştirel düşüncelerini gelişim göstermiştir. Çalışmada, gıda kaynaklı hastalıkları önlemek için, tüketicileri, özellikle çocukları, uygulanacak uygun davranışları öğrenmeyi amaçlayan eğitim deneyimlerine dâhil edilmesinin esas olduğu vurgulanmıştır.

Okullarda güvenli gıdalar ve beslenme eğitimi verilmesi ve okul çağında görülen yetersiz ve dengesiz beslenme ve buna bağlı oluşacak sağlık sorunlarının görülme sıklığı azaltılabilir (Aksoy, 2017: 1; Akçay, 2017: 370). Çünkü büyüme çağındaki çocukların sağlığı bir toplum için gıda güvenliği yönetim farkındalığını zorunlu kılmaktadır. Sağlıklı gıdaların tüketilmesi için gerekli önlemlerin alınması ve gerekli kurallara uyulması gerekmektedir. (Giray ve Soysal, 2007; Sarıkaya, 2007; Özdemir ve Topsümer, 2017: 58). Bu da tüketicinin gıda güvenliği için gerekli duyarlılığı göstermesi gıdalarla ilgili sağılk risklerini ve gıda güvenliğinin sağlanması için gerekli şartları bilmesi ile gerçekleşecektir. Güvenli gıdanın öğrenileceği en etkili yer okullardır. Öğretmenler öğrencilerini sağıklı beslenme konularında bilgilendirip, olumlu tutum ve davranış kazanmalarına yardımcı olarak bireysel gelişimlerine önemli katkı sağlayacaklardır. Bu nedenlerle öğretmenlerin ve öğretmen adaylarının gıda güvenliği hakkında bilgi ve tutumları hem öğrencilerin hem de toplumun bilincini artırmakta önemlidir. Bu araştırma, öğretmen adaylarının gıda güvenliği hakkında bilgi ve tutumlarını belirlemek ve gıda hijyen bilgilerini tespit etmek amacıyla yapılmıştır.

\section{YÖNTEM}

Araştırmada ayrıntılı görüşmelerle katılımcıların bireysel algılarını ve bakış açılarını öğrenmeye yönelik nitel araştırma tekniklerinden fenomenolojik desen kullanılmıştır. Araştırma 2019-2020 akademik yılı güz döneminde Eskişehir ESOGÜ eğitim fakültesi sınıf öğretmenliği son sınıf öğrencisi 14 öğretmen adayı ile gerçekleştirilmiştir. Adayların gıda güvenliğini nasıl algıladıklarına ilişkin görüşleri alınmıştır.

Dijital öğrenme ortamında öğrencilere hazırlanmış açık uçlu soruların yer aldığı dört sorudan oluşan anket formu veri toplama aracı 
olarak kullanılmıştır. İlk soruda adaylara güvenli gıda ve beslenme konusunda eğitim alıp almadıkları sorulmuştur. Bu soru ile adayların gıda ve beslenmeye yönelik ilgilerini belirlenmeye çalışılmıştır. İkinci soruyla güvenli gıda ve sağılılı gıdaya ulaşmaya yönelik davranışları sorulmuştur. Bu soru ile adayların bu konuda güvenilir bilgi ve uygulamalar karşısındaki tutumları belirlenmeye çalışılmıştır. Üçüncü soruyla gıdanın seçimi, yıkanması, pişirilmesi, servisi, saklanması, ısıtılması, tüketilmesine ilişkin bilgileri sorulmuştur. Bu soruyla öğretmen adaylarının güvenli gıda değişkenlerinin izlediği süreç sınanmak istenmiştir. Dördüncü soru ile gıda güvenirliği açısından öğretmen adaylarının arındırma işleminin nasıl yapılacağını bilme durumları öğrenilmeye çalışıımıştır.

Katılımcıların yazılı olarak ifade ettikleri görüşler, bilgisayar ortamına aktarılmış daha sonra analiz için belli başlı olgular belirlenmiştir. Katılımcıların deneyimlerine ilişkin anlamlı yapılar betimlenmiştir. Olgular, kavramsal bir çerçeve içinde değerlendirilmiştir. Geçerlik kapsamında ise yazılı hale getirilen katılımcı görüşleri yine katıımcıların onayına sunulmuştur. Görüşmede ortaya çıkan aksaklıklar doğrultusunda tekrar gerek görülen dil düzeltmeleri yapılmıştır. Araştırma verileri yarı yapılandırıımış görüşme formu ile toplanmıştır. Görüşme formunu oluşturmak için gerekli olan literatür araştırılmış ve uzman desteği ile sorular oluşturulmuştur. 4 sorudan oluşan form 5-10 dakika görüşme süreleri ile adaylara uygulanmıştır.

Araştırmada elde edilen veriler betimsel olarak analiz edilmiş ve adayların sözlerinden doğrudan aktarmalara yer verilmiştir. Aday ve numarası gösterilerek bir kod sistematiği oluşturulmuştur. Bu sistematik örneklemdeki bütün adayların sırayla araştırma bulgularına dâhil edilmesiyle oluşturulmuştur. Araştırma, örneklem büyüklüğü ve araştırmaya gönüllü olarak katılan öğretmen adayları ile sınırlıdır. Araştırma, öğretmen adaylarının gıda güvenirliği farkındalığını arttırması açısından önemlidir.

\section{BULGULAR}

Bu bölümde öğretmen adayları ile yapılan görüşmeler sonucunda elde edilen cevaplar verilmiş ve verilerde öğretmen adayları, A1, A2, ... A14 şeklinde ilgili temalar altında kodlanmıştır. 


\section{Gıda Güvenirliği/Beslenme Konusunda Eğitim Alma Durumuna İlişkin Görüşler}

Araştırmaya katılan öğretmen adayları gıda güvenirliği konusunda başlı başına bir eğitim almadıklarını belirtmişlerdir. Adayların \%79'u bu konuda eğitim almadığını ifade etmişlerdir.

A1: Hayır almadım. Ama 7 Haziran'ın Birleşmiş Milletler Dünya Gıda Güvenliği Günü olduğunu biliyorum ve bunun hakkında bir video izlemiştim. Gıda güvenliği, üretimden tüketicinin sofrasına ulaşana dek gıdalardaki olası fiziksel, kimyasal, biyolojik, mikrobiyolojik ve her türlü zararların öngörülmesini ve uzaklaştırılmasını hedef alan bir kavramdır.

A2: Hayır almadım ancak bu ödev için yaptığım araştırmadan sonra bu eğitimi de almam gerektiğine karar verdim hatta bu eğitimi sadece öğretmenlerin değil tüm anne babaların da alması ve çocuklarına da bu eğitimi vermesi gerektiğini düşünüyorum.

A3: Eğitim almadım ama gıda temizliği konusunda hassasiyetim mevcut. İyice yıkamadan tüketmiyorum. Mevsimi olmayan sebzeleri de tüketmemeye özen gösteriyorum (özellikle domates). Ambalajlı gıdaların hiçbirine güvenmeyip tüketmemekle beraber bazılarını tüketmekten kendimi alıkoyamıyorum.

A4: Eğitim almadım ama gıda temizliği konusunda hassasiyetim mevcut. İyice yıkamadan tüketmiyorum. Mevsimi olmayan sebzeleri de tüketmemeye özen gösteriyorum (özellikle domates). Ambalajlı gıdaların hiçbirine güvenmeyip tüketmemekle beraber bazılarını tüketmekten kendimi alıkoyamıyorum.

A5: Ayrıca bir eğitim almadım fakat annemle yemek yaparken veya alışveriş yaparken söylediği şeylerle ve kendimce doğru olduğunu düşündüğüm şekilde dikkat ediyorum gıdaların raf ömrü, hangi şekilde yapıldı, koruyucu madde bulunup bulunmadığı önemli bir şeydir.

A6: Eğitim almadım ama gıda temizliği konusunda hassasiyetim mevcut. İyice yıkamadan tüketmiyorum. Mevsimi olmayan sebzeleri de tüketmemeye özen gösteriyorum (özellikle domates). Ambalajlı gıdaların hiçbirine güvenmeyip 
tüketmemekle beraber bazılarını tüketmekten kendimi alıkoyamıyorum.

Konu ile ilgili eğitim aldığını belirten üç öğretmen adayının ifadeleri aşağıdaki verilmiştir.

A7: Afganistan' da özel okulda 5. ve 6. Sınıflarda fen dersinde bu konu ile ilgili özel derler verilmektedir. Yılda üç kez Gıda güvenliği ve kirliliği ilgili seminerler verirler. Bu semineler halka açık ve bedava olarak verilmektedir yaş sınırları yoktur. Özel okula gidemeyen öğrenciler bu seminerlerden faydalanmaktadır. Bende bu seminerlere iki kere katılma şansım oldu. Az çok bu konuyla ilgili eğitim aldım diye bilirim.

A8: Türkmenistan da okullarda 1. Sınıftan 10. Sınıfa kadar hayat bilgisi dersi vardır. Bize 9.ve 10. Sınıflarda gıda güvenliği ve kirliliği konusunda eğitim veriyorlar ve seminerler düzenliyorlar. Bizimde bunun gibi eğitimlerden faydalanma şansımız oluyor.

A9: Şu an aldığım sürdürülebilir kalkınma ve eğitim (seçmeli ders) dersinde gıda güvenliği gibi konuları öğrendik.

Adaylardan elde edilen bulgulara göre, öğretmen adaylarının neredeyse tamamının gıda güvenliğine yönelik herhangi bir akademik eğitim almadıkları görülmektedir. Adayların cevapları incelendiğinde büyük bir çoğunluğunun gıda güvenirliği ile ilgili farkındalıklarının olduğu ve bu konuda bir önbilgiye sahip olduğu anlaşılmaktadır. Sağlıklı bir hayat sürebilmenin temel koşulu bu yönde alınan eğitimdir. Çocuklara kazandırılan sağlıklı ve güvenli beslenme alışkanlıklarının bu anlamda önemi büyüktür.

\section{Güvenilir Gıdaya Ulaşmaya Yönelik Davranışlarına İlişkin Görüşler}

Araştırmaya katılan öğretmen adayları güvenilir gıdalara yönelik davranışlarını belirleyen kişisel ilgilerine bağlı olarak sosyal medyadan öğrendikleri ve yakın çevresinden edindikleri deneyimler olduğunu belirtmişlerdir. Öğretmen adayları gıda güvenirliğine ilişkin sahip oldukları bilgilerin \%78'ini internetten, \%43'ünü ailesinden edindiğini ifade etmiştir.

A2: Bazı bilgilerim var elbette ama bunlar bilimsel bilgiden ziyade ailemde öğrendiğim şeyler. 
A3: Ailem ve internetteki çeşitli kaynaklardan

A5: Bilgilerimi daha çok ailemden, internetten ve sosyal mecralardaki paylaşımlardan edindim.

A6: Kendim de bu konuya çok meraklı olduğum için takip ettiğim doktorlar var. İnternetten de bilgiler ediniyorum.

A7: Genellikle annemden ve internetten bilgi ediniyorum.

A8: Bu konuda özellikle son yıllarda yapılan akademik çalışmaları Türkçe ve yabancı kaynaklardan takip etmeye çalışıyorum. Bunlarla ilgili de yine Türk veya yabancı saygın doktorların tavsiye ve araştırmalarını takip etmeye çalışıyorum. Öncelikle bu konularda edindiğim bilgiler dışında, Sağık ve Tarım Bakanlıkları tarafından oluşturulan yönergeler ve bununla ilgili kurulmuş web siteleri sayesinde etiket okumayı ve hangi besini neden almamız veya almamız gerektiği konusunda bilgi sahibi olmaya çalışıyorum. Bunlarla ilgili oluşturulmuş uygulamalar sayesinde de ürün içeriklerinde ve etiketlerinde yazan sembol ve terimlerin ne anlama geldiğini öğrenerek daha bilinçli besin tercihleri yapabiliyorum.

A9: Kitle iletişim araçlarından, sosyal medyadan.

Öğretmen adaylarının güvenilir gıdaya ulaşmalarında izledikleri yolların kendi kişisel çabaları ile edindikleri bilgi ve deneyimler olduğu görülmektedir. Bu nedenle öğretmen adaylarının güvenilir gıdaya erişme çabaları hem kendi öğrencilerinin hem de toplumun bilincini arttırmak açısından önemlidir. Adayların güvenli gıda ile ilgili sistematik ve kapsamlı bilgileri olmamasına rağmen gıda güvenliğini ciddiye aldıkları düşünülmektedir.

\section{Gıdanın Seçimi, Yıkanması, Pişirilmesi, Saklanması, İlişkin Bilgi Düzeyleri}

Öğretmen adaylarının gıda seçiminde, yıkanmasında, pişirilmesinde, saklanmasında ve yeniden tüketilmesinde daha çok ambalajı gıdaları algıladıkları, bu gıdaların üzerindeki ürün bilgilerini okuyup buna uygun hareket ettikleri anlaşılmaktadır. Gıdanın yıkanmasında bol suyun kullanılması, gıdaların soğuk ortamda tutulması ve fazlaca ısıtılmaması gerektiğini düşünmektedirler. 
Öğretmen adaylarının verdikleri cevaplara göre gıdanın seçimi temizliği ve pişirilmesi aşamalarındaki bilgi ve farkındalık düzeyine ilişkin oluşturulan temaları gösteren Tablo 1 aşağıda verilmiştir. 
Tablo 1: Adayların Gıdanın Seçilmesi, Yıkanması, Pişirilmesi, Saklanması Uygulamalarındaki Tutumlarına İliş̧kin İfadelerine Yönelik Oluşturulan Temalar, Yüzde Dağılımı ve Örnek İfadeler

\begin{tabular}{|c|c|c|c|}
\hline Tema & Tema & $\%$ & Öğretmen adaylarının ifadeleri \\
\hline \multirow[t]{4}{*}{$\begin{array}{l}\text { Gıdan } \\
\text {-ın } \\
\text { seçil- } \\
\text { mesi }\end{array}$} & $\begin{array}{l}\text { Son kullanma } \\
\text { tarihi/raf ömrü }\end{array}$ & 50 & $\begin{array}{l}\text { A9: paketli gıdaları alırken son kullanım tarihine } \\
\text { dikkat edilmesi gerektiğini biliyorum. } \\
\text { A3: son kullanma tarihine, } \\
\text { A13: gıdaların raf ömrü, } \\
\text { A6: İlkokuldayken gıdanın seçimi hakkında son } \\
\text { kullanma tarihine bakmamız gerektiğini } \\
\text { öğrenmiştim. }\end{array}$ \\
\hline & $\begin{array}{l}\text { Mevsimine } \\
\text { uygun gidalar }\end{array}$ & 21 & $\begin{array}{l}\text { A8: Mevsimi dışında ne kadar taze ve canlı } \\
\quad \text { görünürse görünsün sebze-meyve veya balık } \\
\text { tüketilmemeli. } \\
\text { A12: Mesela mevsimine uygun gıdalar seçmem } \\
\text { gerektiğini biliyorum. }\end{array}$ \\
\hline & $\begin{array}{l}\text { İçeriği } \\
\text { (Üretim } \\
\text { aşaması ve } \\
\text { içindekiler) }\end{array}$ & 50 & $\begin{array}{l}\text { A2: Günlük hayatımızda tükettiğimiz çoğu } \\
\text { yiyeceğin nerede ne nasıl koşullar altında } \\
\text { üretilip bize ulaştırıldığını bilmiyoruz. Bu } \\
\text { yüzden gıda seçerken içindekiler bölümünü } \\
\text { mutlaka okumaya, bilmediğim içerikleri } \\
\text { araştırmaya } \\
\text { A8: Öncelikle atalık tohumdan üretilmiş ve } \\
\text { kaynağı belli sebze, meyve ve tahılların } \\
\text { tüketilmesi gerekiyor. Hibrit veya organik } \\
\text { tohum kullanılanlar değil. Marketlerde organik } \\
\text { etiketiyle satılan ürünlerin etiketleri okunarak } \\
\text { içerikleri hakkında dikkatli olunmalı. } \\
\text { Bakanlığın onayladığı ve temizlik ve } \\
\text { güvenilirlik konusunda sertifikalı üreticiler } \\
\text { tercih edilmeli. İçerisinde şeker, trans veya } \\
\text { palm yağı, tatlandırıcı, koruyucu bulunan hazır } \\
\text { gıdalar tercih edilmemeli. } \\
\text { A5: Gıda seçiminde içindekiler bölümünü } \\
\text { okuyarak, gıda hakkında bilgi edinirim. } \\
\text { A11: Hammadde kullanma. }\end{array}$ \\
\hline & $\begin{array}{l}\text { Gıdanın } \\
\text { fiziksel } \\
\text { görünümü } \\
\text { koku, tat }\end{array}$ & 36 & $\begin{array}{l}\text { A10: Sebze meyve seçerken fazla pürüzsüz } \\
\text { gözükenlerden uzak durulması gerektiğini } \\
\text { A4: Gıdaları seçerken alacağım gıdada koku } \\
\text { yoğunluğu olup olmadığına dikkat ederim. } \\
\text { Kokusunu alamadığım gıdaları satın almam. } \\
\text { A3: Gıdalar seçilirken gıdanın kokusuna, tadına, } \\
\text { içindekilere dikkat etmeliyiz. } \\
\text { A9: Sağlam bozuk olmayan ve zedelenmemiş } \\
\text { besinler seçilmelidir. }\end{array}$ \\
\hline
\end{tabular}




\begin{tabular}{|c|c|c|c|}
\hline \multirow[t]{3}{*}{$\begin{array}{l}\text { Yıkan- } \\
\text { ması }\end{array}$} & $\begin{array}{l}\text { (Temiz, akan } \\
\text { suda) suda }\end{array}$ & 64 & $\begin{array}{l}\text { A12: Bu sebeple gıdalar hazırlanmadan önce } \\
\text { ellerini temizce yıkamak gerekmektedir ve } \\
\text { hazırlama aşamasında gıda sık sık birkaç kez } \\
\text { yıkama tekrarlaması gerekmektedir. Gıda } \\
\text { hazırlamada aletlerin ve yüzeylerin tümü } \\
\text { yıkanması ve sanitasyonun (sağlıklıönlemleri) } \\
\text { sağlanması. } \\
\text { A14: Gıdaların hazırlanmasında temiz su } \\
\text { kullanmak, özellikle taze yenecek meyve ve } \\
\text { sebzelerin akan su altında yıkanması } \\
\text { gerekiyor. } \\
\text { A3: Gıdayı ellerimizle iyice ovarak yıkamalıyı ki } \\
\text { mikroplardan iyice arınmasını sağlayalım. } \\
\text { A4: Yıkanma noktasında sebze-meyveyi iyice } \\
\text { ovuşturarak temizlemeye gayret gösteririm. }\end{array}$ \\
\hline & Sirkeli suda & 29 & $\begin{array}{l}\text { A1: Gıdalar yıkandığı zaman birçok işlemden } \\
\text { geçmeli ve bu dönemde de bolca sirkeli suyla } \\
\text { yıkanmalıdır. } \\
\text { A7: Özellikle aldığım sebze ve meyveli } \\
\text { sirkeli suda yıkamaya özen } \\
\text { gösteriyorum. } \\
\text { A3: Hatta sebzeleri sirkeli suda bir süre bekletmek } \\
\text { sebzeleri iyi temizleyecektir. }\end{array}$ \\
\hline & $\begin{array}{l}\text { Et ürünlerinin } \\
\text { yıkanmaması }\end{array}$ & 7 & A9: Et ürünlerinin yıkanmaması gerektiğini \\
\hline \multirow[t]{3}{*}{$\begin{array}{l}\text { Pişiril- } \\
\text { mesi }\end{array}$} & Süre & 21 & $\begin{array}{l}\text { A1: Bazı gıdalar çok fazla pişirilmesi gerektiği gibi } \\
\text { hiç pişirmeme durumu da mikrop ve virüs } \\
\text { açısından büyük sorun oluşturur. } \\
\text { A3: Pişirme konusunda ne çok fazla pişirmeli ne de } \\
\text { çiğ olacak kadar az pişirmemeliyiz. }\end{array}$ \\
\hline & Pişirme türü & 14 & $\begin{array}{l}\text { A8. Sebzeler mümkün olduğunca çiğ olarak } \\
\text { tüketilmeli, etler haşlama veya ızgara } \\
\text { yapılmalı, fermente gıdalara da beslenme de } \\
\text { yer verilmeli. } \\
\text { A12: Sebzeleri kızartmak ya da fı̆ınlamak yerine } \\
\text { haşlayarak yemenin daha sağlıklı olduğunu } \\
\text { biliyorum. }\end{array}$ \\
\hline & Sıcaklık & 29 & $\begin{array}{l}\text { A9: Besinlerin pişirilmesi sırasında ısının iyi } \\
\text { ayarlanmasıyla besinlerdeki yararlı etkenler } \\
\text { öldürülmemeli, zararlı mikroorganizmalardan } \\
\text { kurtarılmalıdır. } \\
\text { A11: Gıdaların } 70 \text { derecede pişirilmedi sağlık ve } \\
\text { tüketim açıdan güvenli. Uygun pişirme, } \\
\text { Özellikle et ürünleri gibi gıdaların uygun } \\
\text { pişirilmesi gerekmektedir. Gıdalar uygun } 70 \\
\text { derecede kaynatıldığında mikroorganizmaları } \\
\text { ölüyor. }\end{array}$ \\
\hline
\end{tabular}




\begin{tabular}{|c|c|c|c|}
\hline & $\begin{array}{l}\text { Isıtılma } \\
\text { (sıklığı- } \\
\text { yöntemi) }\end{array}$ & & $\begin{array}{l}\text { A1: Bir yemek ikiden fazla kez ısıtılmamalı ve } \\
\text { belirli bir süre geçtikten sonra o yemek tekrar } \\
\text { tüketilmemeli. Yemeklerin tüketim süresi } \\
\text { vardır. } \\
\text { A3: Saklanma şekli, ısıtılma şekli ve tüketilme } \\
\text { şekli her gıdada farklılık göstereceği için } \\
\text { ambalaj üzerindeki yazıyı dikkate alarak } \\
\text { hareket edebiliriz. } \\
\text { A12: Gıdalar ısıtırken mümkünse mikrodalga } \\
\text { fırınlar gibi sağlıksız yöntemlerin tercih } \\
\text { edilmemesi gerektiğini, zeytinyağlıyemeklerin } \\
\text { Isıtılmaması gerektiğini biliyorum. }\end{array}$ \\
\hline & $\begin{array}{l}\text { Cevap } \\
\text { vermeyen } \\
\text { adaylar }\end{array}$ & 21 & $\begin{array}{l}\text { A5: Dikkat ederim önem veririm. } \\
\text { A6: Cevap yok. }\end{array}$ \\
\hline \multirow[t]{4}{*}{$\begin{array}{l}\text { Sakla } \\
\text { nması }\end{array}$} & $\begin{array}{l}\text { Saklama } \\
\text { sıcaklığı }\end{array}$ & 29 & $\begin{array}{l}\text { A1: Gıdaları saklarken bazı ürünler buzdolabında } \\
\text { saklanması bazı ürünlerin de serin bir dolapta } \\
\text { bulunması gerekir. } \\
\text { A9: Mikroorganizmaların besinde minimum } \\
\text { seviyede bulunması gerekir. Bu durum da } \\
\text { besinlerin ancak tamamıla hijyenik } \\
\text { ortamlarda gerekli önlemler alınarak } \\
\text { saklanmasını gerektirir. Besinlerin temin } \\
\text { edileceği yerlerin hijyeni ve besinin saklama } \\
\text { yöntemi bu konuda çok önemlidir. Bu } \\
\text { besinlerin himayesi sırasında temiz ortamda } \\
\text { saklandığına dikkat edilmelidir. Bozulan } \\
\text { yiyecekler buzdolaplarında bekletilmemelidir. } \\
\text { Çabuk bozulabilen; et, tavuk, balık, yumurta } \\
\text { gibi ürünler satın alındıktan sonra dışarda } \\
\text { bekletilmeden mutlaka buzdolabına konulmalı, } \\
\text { satıldığı yerlerin hijyeninden emin olunmalıdır. } \\
\text { Gıdalar uygun sıcaklıklarda saklanmalıdır. }\end{array}$ \\
\hline & $\begin{array}{l}\text { Saklanılan } \\
\text { malzeme }\end{array}$ & 7 & $\begin{array}{l}\text { A8: Plastikten ziyade cam saklama kapları } \\
\text { kullanılarak, teflon tava yerine çelik, çömlek, } \\
\text { bakır ve döküm tencere-tavalar kullanılmalı. }\end{array}$ \\
\hline & Ortam & 14 & $\begin{array}{l}\text { A4: Arta kalan yemekleri daha sonra tüketmek } \\
\text { için hava almayacak şekilde dolapta saklarım. } \\
\text { A11: Sinek, böceklere karşı korunması } \\
\text { gerekmektedir. Çiğ gıdaların ayrı bir } \\
\text { paketlerde saklanması gerekmektedir. Çünkü } \\
\text { gıdaların suları tehlikeli mikrooganizmalar } \\
\text { içeriyor ve bu gıdaların hazırlanması ve } \\
\text { saklanması sırasında değer gıdalara } \\
\text { geçebiliyorlar. }\end{array}$ \\
\hline & $\begin{array}{l}\text { Saklama } \\
\text { süresi }\end{array}$ & 7 & $\begin{array}{l}\text { A10: Et ürünlerinin yıkanmaması gerektiğini ve } \\
\text { dondurucuda en fazla } 6 \text { ay saklanması } \\
\text { gerektiğini biliyorum. }\end{array}$ \\
\hline
\end{tabular}




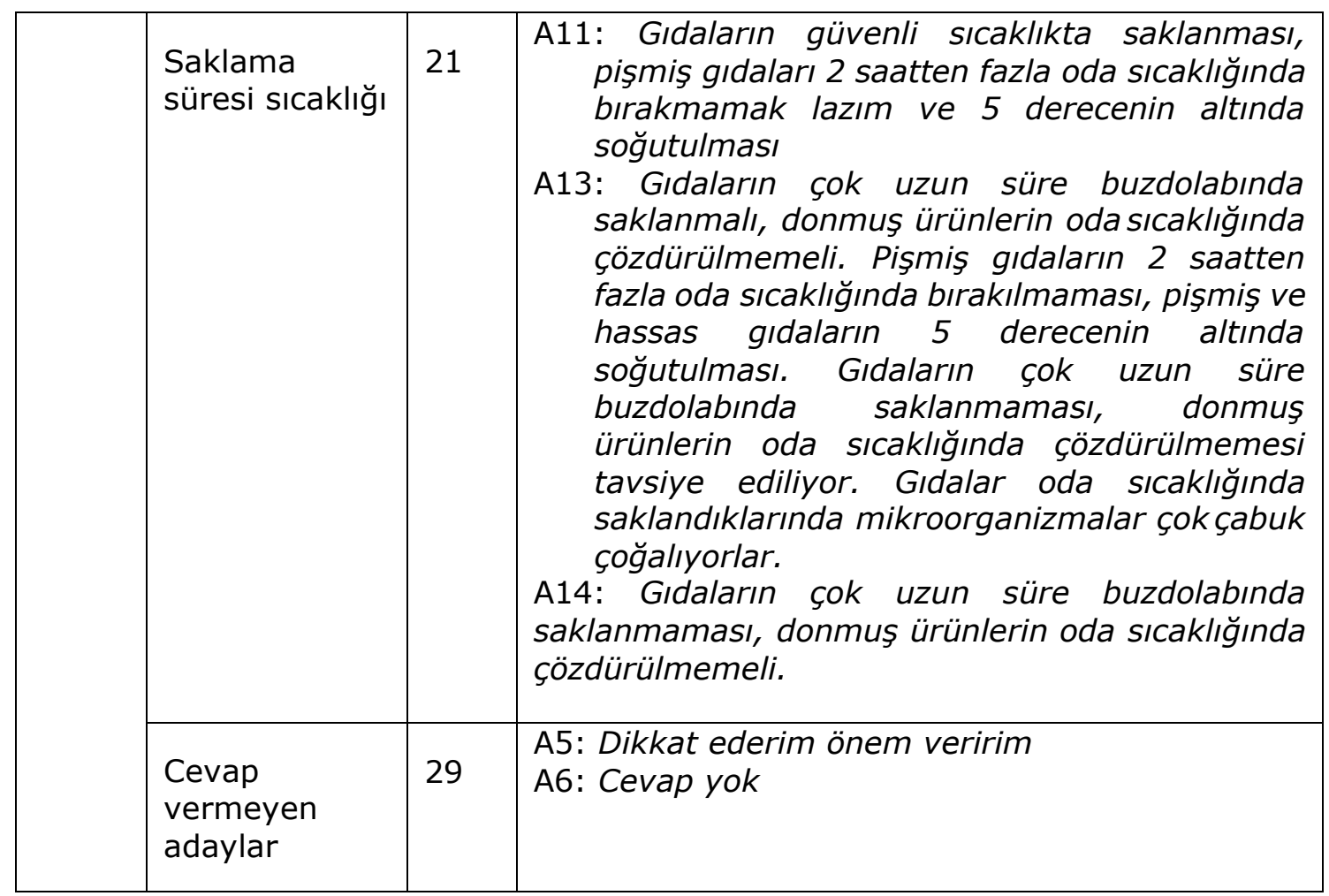

Bilinçli ve güvenli gıda tüketimi konusunda adayların bilinçli bir standart tüketici gibi ürün üzerindeki bilgilere dikkat ettikleri, gıdanın alındıktan sonra tüketime kadar geçen süre içerisindeki süreci takip ettikleri görülmektedir. Ancak gerek bilgi kirliliği gerekse doğru bilinen yanlışlar nedeniyle gıda tüketimleri olabilmektedir. Tüketicinin gıda maddesinin taşıması gereken kalite ve tüketim kriterlerini bilmesi ve uygulaması standart bir prosedürdür. Öğretmen adaylarının gıdanın seçilmesi, saklanması, pişirilmesi, ısıtılması konusunda nispeten bilgi bilinç ve duyarlılıklarının olduğu görülmüştür.

\section{Gıda Güvenirliği Açısından Arındırmanın Nasıl Yapacağını Bilme Durumları}

Gıdaları sağlığa zararlı hale getiren fiziksel, kimyasal, biyolojik etmenlerdir. Tüketicilerin yanlış uygulamaları ve tüketim sırasındaki uygun olmayan koşullar nedeniyle gıda hijyeni olumsuz olarak etkilenmektedir. Adayların çoğu gıdalardaki fiziksel, biyolojik ve kimyasal arındırmanın nasıl yapılacağını tam olarak bilmemektedir.

Çalışma kapsamında öğretmen adaylarının gıda güvenliği açısından arındırmanın farkındalık düzeyine ilişkin oluşturulan temaları gösteren Tablo 2 aşağıda sunulmuştur.

Tablo 2: Adayların Gıdanın Arındırma İşlemlerindeki Tutumlarına İlişkin İfadelerine Yönelik Oluşturulan Temalar, Yüzde Dağılımı ve Örnek İfadeler 


\begin{tabular}{|c|c|c|}
\hline $\begin{array}{l}\text { Arındırma } \\
\text { işlemleri }\end{array}$ & $\%$ & Öğretmen Adaylarının İfadeleri \\
\hline $\begin{array}{l}\text { Fiziksel } \\
\text { Arındırma }\end{array}$ & $\begin{array}{l}2 \\
9\end{array}$ & $\begin{array}{l}\text { A8: Izgara veya süzgeç gibi bir materyalle yapılan } \\
\text { arındırma işlemidir. } \\
\text { A9: Fiziksel arındırma yöntemi ise yüzeysel olarak } \\
\text { gıdaların hijyeninin sağlanmasıdır. } \\
\text { A13: Yemek hazırlığı yapılırken kemik parçaları, } \\
\text { çekirdekler, taş, cam, ezik çürük kısımlar } \\
\text { gıdalardan uzaklaştırılmalıdır. Üretim içerisinde } \\
\text { personel takı veya mücevher takmamalı, ellerde } \\
\text { yara varsa yara bantları sık aralıklarda } \\
\text { değiştirilmelidir. Kırık ekipman kullanılmamalıdır. } \\
\text { Üretim içerisine dış ortamdan sinek, böcek, haşere } \\
\text { gibi yabanc maddelerin girmesine engel olmak } \\
\text { gerekir. }\end{array}$ \\
\hline $\begin{array}{l}\text { Kimyasal } \\
\text { Arındırma }\end{array}$ & $\begin{array}{l}3 \\
6\end{array}$ & $\begin{array}{l}\text { A8: Kimyasal arındırma ise zararlı veya kirlilik } \\
\text { oluşturan maddelerin çökelti haline gelerek } \\
\text { ayrıştırılması. } \\
\text { A11: Pazardan soframıza kadar gelen sebze ve } \\
\text { meyvelerin üzerinde birçok kimyasal madde } \\
\text { mevcut. Organik ürün satan yerel pazarlardan } \\
\text { alışveriş etmediğiniz müddetçe aldığınız her sebze } \\
\text { ve meyvede bir miktar böcek ilacı bulunabilir. Bu } \\
\text { ilaçlar ekinlerin yetiştirilmesi sırasında sıkılır ve } \\
\text { çoğu zaman bitkinin üzerinde kalır. Bu kimyasallar } \\
\text { gözle görülmeyecek kadar küçük partiküllerden } \\
\text { oluşur. Eğer sebze ve meyveyi düzgün biçimde } \\
\text { yıkanmadan çiğ olarak tüketirsek bedenimize } \\
\text { zararlı kimyasal alıyoruz demektir. }\end{array}$ \\
\hline $\begin{array}{l}\text { Biyolojik } \\
\text { Arındırma }\end{array}$ & $\begin{array}{l}2 \\
9\end{array}$ & $\begin{array}{l}\text { A1: Çeşitli maddelerle sterilizasyon gerçekleştirdiği } \\
\text { A8: Biyolojik arıtma ise su içerisindeki organik } \\
\text { maddelerin bakteriyolojik yöntemlerle } \\
\text { ayrıştırılmasına denir. } \\
\text { A9: Biyolojik Arındırma Yöntemi; herhangi bir kimyasal } \\
\text { madde kullanmaksızın atık su içerisinde } \\
\text { yetiştirilecek olan mikroorganizmalar sayesinde, } \\
\text { kirliliğe sebebiyet veren maddelerin yok edilmesine } \\
\text { dayanan bir arıtma şeklidir. } \\
\text { A14: Biyolojik arındırma; yiyecekleri hazırlarken } \\
\text { mikroorganizma bulaşmalarını önlemek için şu } \\
\text { hususlara dikkat etmek gerekir. Güvenli } \\
\text { hammadde seçilmeli pişirme işlemi tam olarak } \\
\text { gerçekleştirilmeli, pişmiş gıdalar kısa sürede } \\
\text { tüketilmeli, tam tüketilmeyen yiyeceklerin } \\
\text { muhafazasına dikkat edilmeli, tekrar ısıtma işlemi } \\
\text { gerekiyorsa iyi derecede ısıtılıp tüketilmeli ve } \\
\text { yiyeceğin hazırlandığı ortam sürekli temiz tutulup } \\
\text { dezenfekte edilmelidir. }\end{array}$ \\
\hline $\begin{array}{l}\text { Cevap } \\
\text { vermeyen } \\
\text { adaylar }\end{array}$ & \begin{tabular}{|l|}
5 \\
0
\end{tabular} & \\
\hline
\end{tabular}


Adayların beslenme ve gıda tüketimi konusunda duyarlı, bilinçli ve öğrenmeye meraklı oldukları söylenebilir. Kendi şartları doğrultusunda doğru bilgiye ulaşma çabasında olduklarını kendileri de ifade ettiler.

A8'in "Bu konuda özellikle son yıllarda yapılan akademik çalışmaları Türkçe ve yabancı kaynaklardan takip etmeye çalışıyorum. Bunlarla ilgili de yine Türk veya yabancı saygın doktorların tavsiye ve araştırmalarını takip etmeye çalışıyorum. Öncelikle bu konularda edindiğim bilgiler dışında, Sağlık ve Tarım Bakanlıkları tarafından oluşturulan yönergeler ve bununla ilgili kurulmuş web siteleri sayesinde etiket okumayı ve hangi besini neden almamız veya almamı gerektiği konusunda bilgi sahibi olmaya çalışıyorum. Bunlarla ilgili oluşturulmuş uygulamalar sayesinde de ürün içeriklerinde ve etiketlerinde yazan sembol ve terimlerin ne anlama geldiğini öğrenerek daha bilinçli besin tercihleri yapabiliyorum" ve A9' un "Beslenme konusunda bir eğitim almadım. Mesleki olarak; mesleğe başlamadan önce, öğrencilerin beslenme bozukluklarının belirtilerine yönelik seminerler, konferanslar aracılığıyla uzmanlar tarafından aday öğretmenlere aktarılabilir. Okullarda beslenme düzenine yönelik sunumlar yapılabilir örneğin; tüketici haftasında. Gıda güvenliği, nasıl saklanması gerektiği, gıdaların temizliği konusunda eğitimler almak isterdim."

Şeklindeki ifadeleri bu konuda doğru bilgiyi edinme hususunda verilecek her türlü etkinlik içinde olmaya gönüllü olduklarının bir göstergesidir. Buna benzer ifadeler neredeyse araştırmadaki adayların neredeyse tamamı kullanmıştır. Burke ve Dworkin (2015) yaptıkları çalışmada öğrencilerinin gıda güvenliği bilgilerinin kendilerini korumak için yetersiz olduğunu ve öğrenciler arasında gıda güvenliği bilgisi eksikliğini, kısmen resmi gıda güvenliği eğitimi eksikliğine bağlamışlardır. Barrett ve diğerleri Amerika Birleşik Devleti'ndeki devlet okullarındaki gıda güvenliğine yönelik ders uygulamalarını değerlendirirken birçok gıda güvenliği programının, tamamlayıcı materyal olarak hizmet ettiğini ve sınıf uygulamasından önce akademik standartlara uyarlanmasının gerekliliğinden bahsetmişlerdir. Araştırmacılara göre değişen akademik standartlara uyum, gıda güvenliği konularının temel disiplinlere dâhil edilmesini gerektirir (Barrett vd., 2020). Çocuk kitapları yoluyla matematik becerilerinin 
kazandırılmasına yönelik yapılmış araştırmaların incelenmesine yönelik yürütülen bir çalışmada Kanada'da, 77 lise öğrencisinin gıda güvenliği bilgi ve tutumlarının, gıda ve beslenme kurslarında verilen bir eğitim müdahalesinin ardından öğrenci bilgisinin önemli ölçüde arttığı görülmüştür (Majowicz vd., 2017).

Brewer ve Rojas (2008), tüketicilerin \%47 sinin güvenli gıda tükettiklerini düşündükleri, gıda kaynaklı hastalıklara yakalananların $\% 25,5^{\prime}$ inin okullarda tükettikleri besinlerden dolayı hastalıklara yakalandıkları; Unusan (2007), gıda güvenliği uygulamaları konusunda eğitim seviyesinin artmasıyla gıda güvenirliğine ilişkin bilgilerinin de arttığını; Albayrak (2000), tüketicilerin gıdayı satın alırken üretim ve tüketim tarihine dikkat ettikleri; Küçükköse (2002), bilinçli tüketicilerin ambalajın sağlamlığına dikkat ettikleri; Yurdagül, (1991), tüketicilerin \%66,3 ünün etiket bilgilerini okumadıklarını; Kolondinsky ve diğerleri (2008), üniversite öğrencilerinin gıda satın alma tercihlerinde fiyatının etkili olduğunu tespit etmişlerdir (akt. Alpuğuz vd., 2009: 112).

Dölekoğlu (2003), araştırmasında gıda güvenirliğine ilişkin eğitimlerin verilmesi toplumsal bilinci yükselttiği, Aslan ve Çakıroğlu (2004) verilen hijyen eğitiminin bilgi düzeyini arttırdığını, Şanlıer (2009), gıda güvenliği bilgilerinin uygulamaları da olumlu yönde etkilediği, Büyükünal (2005) öğretmenlere gıda güvenirliği konusunda toplumu bilinçlendirme açısından büyük görevler düştüğünü tespit etmişlerdir (akt. Kocaman ve Şanlıer, 2014: 155). Bu bulgular doğrultusunda gerek gıdanın seçimi gerekse tüketilmesine ilişkin izlenecek aşamaların bilinçli ve sistemli bir şekilde yapılmadığı sonucuna ulaşılmıştır. Araştırmamızın sonuçları ile paralellik gösteren bu durum, gıda güvenirliği açısından izlenecek standartların belirlenmesi ihtiyacını ortaya koymaktadır.

\section{SONUÇ VE ÖNERİLER}

Araştırma sonuçlarına göre; adayların gıda güvenirliğine ve sağlıklı beslenmeye ilişkin herhangi bir ders almadıkları, gıda güvenirliği ile ilgili bilgileri kişisel çabaları ile sosyal medya ve yakın çevrelerindeki deneyimlerden edindikleri, tarladan sofraya gelen gıdaların izledikleri süreçte yapmaları gerekenleri tam olarak bilmedikleri, ambalajlı gıdaları alırken üzerindeki açıklamalara göre bilgi edindikleri, gıdaları iyice yıkayıp tükettikleri ancak gıdaların arındırılma yollarını tam olarak bilmedikleri sonucuna varılmıştır. Rastgele seçilen örneklem içerisinde yer alan Afganistan ve 
Türkmenistan uyruklu 2 adayın ise ilköğretim döneminde gıda güvenirliği ile ilgili bir eğitim aldıkları belirlenmiştir. Geleceğin öğretmenlerinin hizmet öncesi güvenli ve sağlıklı gıda eğitimi almaları hem onların hem öğrencilerinin dolayısıyla toplumun bu konudaki bilgi ve becerisini arttıracak bir faktördür. Araştırmanın adaylardaki hem yürütecekleri mesleğin sorumluk bilinci ile hem de bilinçli ve sağlıklı bir tüketici olma amacını güderek gıda güvenirliğine yönelik akademik düzeyde eğitim alma isteklerini ve bireysel olarak bu konudaki güvenilir bilgiye ulaşma çabalarını görmek açısından önemli olduğunu düşünüyoruz.

Öğrenciler okul öğrenme ortamlarında gıda güvenliği ve sanitasyon davranışlarını güçlendirmek amacıyla gıda alırken dikkat edilecek hususlar ve gıda muayenesine yönelik simülasyona ve öğrenmeye büyük önem vermektedir (Soares vd., 2013). Araştırmacılara göre eğitim ve öğretim gerçekten sahadaki birçok tehlikeyi tespit etmeye yardımcı olur ve büyük ölçüde azaltabilir. Eğitim sırasında el temizliği ve genel arındırma talimatları yazılara veya sloganlara dönüştürülmelidir. Öğretim ve öğrencilerin temizlik alışkanlıkları edinmeleri için eğitiminin yanı sıra eğitim içerikleri de gıda güvenliğini artırmaya büyük ölçüde yardımcı olabilir (Ababio vd., 2016).

Araştırma bulgularına dayalı olarak, adayların ilkokuldan başlayarak hizmet öncesi eğitime kadar gıda güvenirliği ve beslenme ile ilgili eğitimleri almaları, besinlerin tarladan sofraya kadarki yolculuğunda bilinçli bir tüketici olarak yapılması gerekenlerin uygulamalarına yer verilmesi, adayların beslenmeleri ve gıda güvenirliği deneyimlerini ortaya koyabilecek bilimsel araştırmaların yapılması önerilmektedir.

\section{KAYNAKÇA}

Ababio, P. F., Taylor, K. D. A., Daramola, B. A. \& Swainson, M. (2016). Food Law Compliance in developed and Developing Countries: Comparing School Kitchens in Lincolnshire-UK and Ashanti Region of Ghana. Food Control 68, 167-173.

Akçay, S. (2017). Öğretmen Adaylarının Genetiği Değiştirilmiş Gıdalar İle İlgili Algıları. NEF-EFMED 11(2), 365-382.

Aksoy, M. (2017). Okul Kantinlerine İlişkin Öğrenci, Öğretmen, Yönetici ve Veli Görüşleri. (Yayımlanmamış Yüksek Lisans Tezi). Pamukkale Üniversitesi, Eğitim Bilimleri Enstitisü, Denizli. 
Albayrak, M. (2000). Ankara İlinde Gıda Maddeleri Paketleme ve Etiketleme Bilgileri Hakkında Tüketicilerin Bilinç Düzeyinin Ölçülmesi, Gıda Maddeleri Alım Yerleri ve Ambalaj Tercihleri Üzerine Bir Araştırma. Ankara: Türkiye Ziraat Odaları Birliği Yayınları.

Alpuğuz, G., Erkoç, F., Mutluer, B. \& Selvi, M. (2009). Gençlerin Gıda Hijyeni Ve Ambalajlı Gıdaların Tüketimi Konusundaki Bilgi ve Davranışlarının İncelenmesi. Türk Hijyen ve Deneysel Biyoloji Dergisi 66(3), 107-115.

Artık, N., Poyrazoğlu, E. \& Konar, N. (2013). Her Yönüyle Gıda Kitabı. Türk Gıda Mevzuatı ve Gıda Denetimi Bölümü. İzmir: Sidaş Yayıncilık.

Barett, T. E., Feng, Y. \& Wang, H. H. (2020). Food safety in the Classroom: Using the Delphi Technique to Evaluate ResearcherDeveloped Food Safety Curriculum Aligned to State Academic Standards. Journal of Food Science Education 19, 152-162.

Brewer, M. S. \& Rojas, M. (2008). Consumer Attitudes Toward Issues in Food Safety. Journal of Food Safety 28, 1-22.

Burke, A. \& Dworkin, M. (2015). How Knowledgeable are High School Students About Food Safety? Results from a Predominantly Minority Chicago Charter School. British Food Journal 117(6), 1737-1752.

Büyükünal, S. K. (2005). Gıda Güvenliğinde Personel Eğitiminin Önemi. Gıda 62, 48-50.

Çetin, A. S. \& Şahin, B. (2017). Gıda Güvenliğinde Risk Faktörleri ve Hijyenin Önemi. Journal of Tourism and Gastronomy Studies 5(2), 310-321.

Dong, T. T. M. \& Ching, G. S. (2015). A Case Study on the Food Safety İssues of College Students in Taiwan. Int J Res Stud Manage 4, 37-58.

Dölekoğlu, C. Ö. \& Yurdakul, O. (2004). Adana İlinde Hane Halkının Beslenme Düzeyleri ve Etkili Faktörlerin Logit Analizi ile Belirlenmesi. Akdeniz İ.I.B.F. Dergisi 8, 62-86.

Erkmen, O. (2010). Gıda Kaynaklı Tehlikeler ve Güvenli Gıda Üretimi. Çocuk Sağlığı ve Hastalıkları Dergisi 53, 220-235.

Giray, H. \& Soysal, A. (2007). Türkiye'de Gıda Güvenliği ve Mevzuatı. TSK Koruyucu Hekimlik Bülteni 6(6), 485- 490. 
Güler, Ç. \& Çobanoğlu, Z. (1994). Su Kirliliği, Çevre Sağlığı Temel Kaynak Dizisi No. 12, T.C Sağlık Bakanlığı Sağlık Projesi Genel Koordinatörlüğü. T.C Sağlık Bakanlığı Temel Sağlık Hizmetleri Genel Müdürlüğü, Ankara.

Gündoğdu, Z., Keskindemirci, G., Aksakal, M. T., Aşkan, Ö. \& Gökçay, O. G. (2016). Fiziksel Çevre Kirliliğinin Çocuk Sağlığına Etkileri. Çocuk Dergisi 16(3-4), 60-66.

Harmanoğulları, Ü. L. \& Yapıcı, G. (2018). Bir İlçede Bulunan Okul Kantinlerinin Hijyen Koşulları ve Gıda Güvenliği Açısından Değerlendirilmesi. Turk J Public Health 16(2), 117-130.

Hasançebi, K. B. E. (2010). Öğretmenlerin Organik Gıdaları Tercih Etme Durumlarının Saptanması. (Yayımlanmamış Yüksek Lisans Tezi). Gazi Üniversitesi, Eğitim Bilimleri Enstitisü, Ankara.

İncedal-Sonkaya, Z., Balcı, E. \& Ayar, A. (2018). Üniversite Öğrencilerinin Gıda Okuryazarlığı ve Gıda Güvenliği Konusunda Bilgi, Tutum ve Davranışları. Türk Hijyen ve Deneysel Biyoloji Dergisi 75(1), 53-64.

Kaplan, M. (2009). Organik Gıdalar Neden Tercih Edilmeli? TÜBİTAK Bilim ve Teknik Dergisi 501, 30-33.

Kocaman, E. M. \& Şanlıer, N. (2014). Öğretmenlerin Gıda Güvenliği Bilgi Düzeylerinin Tutumlarına Etkisi. Taf Prev Med Bull 13(2), 151-160.

Kolodinsky, J., Green, J., Michahelles, M., Harvey-Berino, J. R. (2008). The Use of Nutritional Labels by College Students in a Food-Court Setting. Journal of American College of Health 57(3), 297-301.

Küçükköse, Ş. (2002). Farklı Öğrenim Düzeyindeki Tüketicilerin Süpermarketlerden Gıda Alışverişlerinde Etkilendikleri Faktörler. (Yayımlanmamış Yüksek Lisans Tezi). Eğitim Bilimleri Enstitüsü Aile Ekonomisi ve Beslenme Anabilim Dalı, Gazi Üniversitesi, Ankara.

Majowicz, S. E., Hammond, D., Dubin, J. A., Diplock, K. J., JonesBitton, A., Rebellato, S. \& Leatherdale, S. T. (2017). A Longitudinal Evaluation of Food Safety Knowledge and Attitudes Among Ontario High School Students Following a Food Handler Training Program. Food Control 76, 108-116. 
Onurlubaş, E. \& Gürler, Z. A. (2016). Gıda Güvenliği Konusunda Tüketicilerin Bilinç Düzeyini Etkileyen Faktörler. JAFAG 33(1), 132-141.

Özdemir, K. E. \& Topsümer, F. (2017). Güvenilir Gıda Konusunda Tüketici Farkındalığının Geliştirilmesinde İletişim Stratejilerinin Rolü. EGEMİA 1, 57-84.

Sarıkaya, N. (2007). Organik Ürün Tüketimini Etkileyen Faktörler ve Tutumlar Üzerine Bir Saha Çalışması. Kocaeli Üniversitesi Sosyal Bilimler Enstitüsü Dergisi 14(2), 110-125.

Sarıtaş, A. (2012). Öğretmenlerin Organik Gıdalara Yönelik Görüşlerini Etkileyen Faktörler. (Yayımlanmamış Yüksek Lisans Tezi). Selçuk Üniversitesi, Sosyal Bilimler Enstitüsü, Konya.

Soares, K., Garcı'a-Dı' ez, J., Esteves, A., Oliveira, I., Saraiva, C., (2013). Evaluation of Food Safety Training on Hygienic Conditions in Food Establishments. Food Control 34, 613-618.

Travers, A., Adriano, D., Bellio, A., Bianchs, D. M., Gallina, S., Ippolito, C., Romano, A., Durelli, P., Pezzano, A. \& Decastelli, L., (2017). Food Safety and Sustainable Nutrition Workshops: Educational Experiences for Primary School Children in Turin, Italy. Italian Journal of Food Safety 6(1), 9-12.

Unusan, N. (2007). Consumer Food Safety Knowledge and Practices in the Home in Turkey. Food Control 18(1), 45-51

Yurdagül, M. (1991). Tüketicilerin Gıda Katkı Maddeleri ile İlgili Bilgi ve Uygulamaları. Beslenme ve Diyet Dergisi 20(2), 199-208. 